\title{
Risk Attributes, Influencing the Time and Cost Overrun in Joint Venture Construction Projects of Pakistan
}

\author{
Muhammad Akram Akhund \\ Department of Civil Engineering \\ ISRA University \\ Hyderabad, Pakistan \\ akhund42@gmail.com
}

\author{
Ali Raza Khoso \\ Department of Civil Engineering \\ Mehran University of Engineering \& \\ Technology, Jamshoro, Pakistan \\ aliraza.khoso@faculty.muet.edu.pk
}

\author{
Ashfaque Ahmed Pathan \\ Department of Civil Engineering \\ Mehran University of Engineering \& \\ Technology, Jamshoro, Pakistan \\ ashfaquepathan2003@gmail.com
}

\author{
Hafiz Usama Imad \\ Department of Civil Engineering \\ ISRA University \\ Hyderabad, Pakistan \\ usama.imad@isra.edu.pk
}

\author{
Fida Siddiqui \\ Department of Civil Engineering \\ Mehran University of Engineering \& Technology \\ Jamshoro, Pakistan \\ fidasiddiqui2@gmail.com
}

\begin{abstract}
Business collaborations formed by construction contractors to enhance their abilities and effectiveness in large construction projects are known as construction joint ventures (CJVs). It is widely used as a way of merging assets, capitals, funds, resources and expertise of different organizations. It helps business to grow faster, increase efficiency and generate greater profits without borrowing money. Though it is useful and beneficent for the vendors, it may contain several types of risk. It is both beneficial and stimulating due to differing technical skills, economic and political atmospheres, and cultural and legal backgrounds. Recent development and modernization in Pakistan have led it towards a new construction phase, which involves national and multinational joint venture projects. Global and local CJVs have become gradually prevalent to produce mega construction projects. Current research aims to investigate and to identify the communal, ecological, political, legal, economic and other external risks associated with CJV projects in Pakistan. The study was carried out by literature review and a few national and international guidelines. Interviews were conducted with relevant professionals, experts, and owners of the organizations working on CJV projects. Data was collected in the form of a questionnaire from relevant professionals. The descriptive analysis was performed through SPSS using average index (A.I) technique. This study is helpful for the Government of Pakistan, public and private construction firms working under JV to reduce the emerging risks of construction projects.
\end{abstract}

Keywords-joint venture; risk; construction; Pakistan

\section{INTRODUCTION}

Developing countries usually prioritize to invest in construction and infrastructure development [1]. Infrastructure development and mega construction projects need huge financial and human resources. Building complex engineering projects requires prominent level of expertise, sophisticated machinery and well managed teams with sufficient monetary resources, which is often beyond the scope of a single contractor. A joint venture (JV) is a commercial alliance between two or more separate entities that offers a unique opportunity to combine the distinctive competencies, increase the capacity of advantages and the complementary resources to participating firms [2]. Construction joint ventures (CJVs) have nowadays become more popular because of their importance as a strategic alternative in global competition and its vast advantages to the concern entities. In CJVs, two or more independent partners ally to achieve their goals [3]. All the terms and conditions of the alliance are pre-agreed between the parties, something that stipulates the conditions of partnership including work distribution, profit sharing, resource contribution and conflict resolution [4, 5]. For multinational and international projects, the alliance is made between local and foreign teams. This type of association is termed as international construction joint venture (ICJV) [6]. It is extensively used to improve the capacities of partners and competitiveness of the CJV [7].

Due to the change in the globalized and modern demands of construction many studies carried out regarding construction procurement methods have revealed that there needs to be a change of culture and attitude in the construction industry, moving away from traditional adversarial relationships to cooperative and collaborative relationships [8-11]. There are increasing concerns on improving the industry by alternative procurement methods, involving a movement away from traditional procurement systems [12]. JVs possess a lot of advantages, but they also offer a high level of uncertainty. 
Despite the benefits associated with IJVs, the failure rate is high, higher than those of the domestic JVs because IJVs generally face greater challenges [13]. IJVs are also risky due to the complexity of management and operation issues [14]. The variation in working environment between foreign and local markets has a considerable influence on the performance of an ICJV project [15]. Despite the fact that international business corporations have provided many opportunities, which ultimately have benefited this industry [16], ICJV has familiarized a variety of new risks which differ from the usual [17]. Several threats like cultural diversity, language barriers, lack of information regarding the host country, legislative variations, currency exchange, and difference in climatic conditions are adhered with the glittering opportunities that attract contractors towards IJCVs. Excessive planning and early identification are the preventive measures that can cater these risks [18]. Risk observation is a complex procedure. It has different implications to different persons that vary according to the confidence, knowledge, and viewpoints [20]. Risk is the likelihood of existence and the level of effect of a negative incident negatively influencing an activity. Risk, as an ambiguous occasion, is the combination of the severity, probability, brutality and exposure of all threats and hazards of an action intimidating project achievement [21]. Authors in [22] framed a hierarchy structure of the risks affecting to JVs and established an AHP model for the judgement of the risk environment [23]. In recent years, in Pakistan, a lot of advancement is being made due to the CPEC projects, so it offers new opportunities for the local as well the multinational construction firms to work under JVs with increased scope of work. But the real issue is that attention is not being paid to form new laws to address the risk involving in international construction joint ventures in Pakistan. So, this study highlights the risk associated with CJVs in Pakistan by reviewing national and international guidelines about JVs. It is based on international literature review and its applicability in the local market has been reviewed in the form of a questionnaire survey. The results from the questionnaire survey are analyzed through SPSS.

\section{RESEARCH METHODOLOGY}

The objective of this research is to highlight the risks associated with CJV projects in Pakistan. To approach a proper resolution of this problem, a step by step methodology was adopted. The main causes were selected and then discussed with field experts. An inclusive literature review was conducted to set a standard for this study and to support the questionnaire development. The questionnaire comprised questions meant to profile the companies that participated in it. The experts who had the experience on JVs participated in data collection. In addition, a total of 6 main categories of risks under which total 48 risk factors were collected from the literature review were offered in the questionnaire and the respondents were requested to rate the probability of occurrence and the degree of impact for each risk. After conducting unstructured interviews with experts and construction industry players, more risk factors were added which are common in the construction industry of Pakistan. The survey was conducted among construction industry stakeholders i.e. owners, consultants, and contractors. After collecting the data, the analysis was done through SPSS (statistical packages for social sciences). Then the most critical factors were selected as main causes of a changed order in the construction industry of Pakistan. These causes were then discussed with the relevant experts in the context of Pakistan construction industry. Figure 1 shows the detailed research methodology.

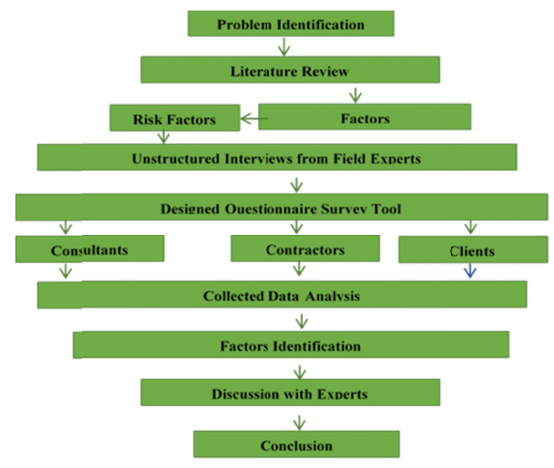

Fig. 1. Research methodology

\section{DATA COLLECTION AND ANALYSIS}

The designed questionnaire was divided into two parts. The first part consisted of participant's demographic information. The second part contained the risk factors in CJV firms of Pakistan. Respondents were requested to rank the risk factors in JV firms which are affecting the construction project duration and estimated cost. The ranking scale ranges from 1 to 5,1 meaning that the mentioned factor is not significantly affecting the duration and cost while 5 means that the factor has high impacts on duration and cost of the project. The questionnaire was distributed among 180 professionals related to the construction field, mainly from three major stakeholder categories, namely clients, consultants, and constructors. To have a better understanding of the issue, different scale projects varying between 5 million to 3500 million Pakistani Rupees, were considered. All major fields including residential, commercial, public amenities, roads, and bridges etc. are covered for data collection. Respondents included in the survey had a wide range of experience, so the data were reliable. Figure 2, shows the respondents' range and position. Their positions are associated with their experience. The opinion of respondents at key positions is more worthy than the opinion of those on lower positions. Average index technique methods were used for identifying the risk factors in JV firms of Pakistan construction industry. [24-25]. All demographic information is summarized in Table I.

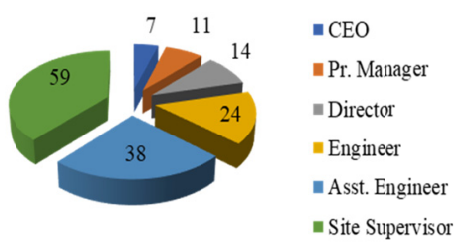

Fig. 2. Position of respondents 
TABLE I. DEMOGRAPHIC RESULTS

\begin{tabular}{|c|c|c|c|}
\hline & Frequency & Percentage (\%) & Cumulative \% \\
\hline \multicolumn{4}{|l|}{ Organization Type } \\
\hline Client & 68 & 44.44 & 44.44 \\
\hline Consultant & 33 & 21.58 & 66.02 \\
\hline Constructor & 52 & 33.98 & 100.00 \\
\hline \multicolumn{4}{|l|}{ Project Size } \\
\hline$<20$ million & 21 & 13.73 & 13.73 \\
\hline 20-40million & 46 & 30.06 & 43.79 \\
\hline 50-150million & 14 & 9.15 & 52.94 \\
\hline 150-400million & 12 & 7.84 & 60.78 \\
\hline 400-800million & 16 & 10.46 & 71.24 \\
\hline $800-1800$ million & 23 & 15.03 & 86.27 \\
\hline 1800-3000million & 10 & 6.53 & 92.80 \\
\hline$>3000$ million & 11 & 7.20 & 100.00 \\
\hline \multicolumn{4}{|l|}{ Project Type } \\
\hline Commercial & 46 & 30.06 & 30.06 \\
\hline Roads & 30 & 19.60 & 49.66 \\
\hline Residential & 32 & 20.91 & 70.57 \\
\hline Social Amenities & 21 & 13.72 & 84.27 \\
\hline Bridges & 24 & 15.73 & 100.00 \\
\hline \multicolumn{4}{|l|}{ Working Experience } \\
\hline $0-5$ years & 62 & 40.52 & 40.52 \\
\hline $6-10$ years & 23 & 15.03 & 55.55 \\
\hline $11-15$ years & 33 & 21.57 & 77.12 \\
\hline $16-20$ years & 13 & 8.50 & 85.62 \\
\hline More than 20 Years & 22 & 14.38 & 100.00 \\
\hline
\end{tabular}

\section{RESULTS AND DISCUSSION}

All influencing factors are categorized into six categories namely cultural, contractual, financial, managerial, legal and political. The average score of Liker's scale by each type of respondent is listed in Tables II-VII. Average index and standard deviation of factors are also listed in front of each factor. It is observed that unidentified organizational goals are the highest ranked factor among the factors in the contractual category. The average score from clients is higher than the one of the other two types of respondents. It is clearly evidenced that regarding the opinion of clients this factor is responsible for the time and cost overrun of the project. For mega projects, where the team is large and consists of members having diverse cultural and lingual background, language barriers is of the highest concern and ranked 1st in the category of cultural attributes. The pattern of work and its difference with the difference in the background of the worker is the least concerning issue in this category. Similarly, price escalation, distrust, lack of laws and political influence are top-ranking attributes in each category respectively. Difference of opinion exists in clients, consultants and constructors, but on average the above-mentioned factors are identified as the most risky and most critical in their respective category. Overall sudden policy change and other political issues are highlighted as crucial features which can cause delays and can raise other complexities in JV projects.

\section{CONCLUSION}

JVs in construction are growing day by day due to their increased work capacity, so this study just highlights the points related to project risks. In future, the JVs would be more embraced in the field of construction. Further work can be done in order to resolve the issues regarding the Pakistan law, because new laws must be introduced for JVs. Risks of being delayed and being the defaulter of the project become more crucial in JV projects. Among 48 critical attributes responsible for causing undesired interruptions in the project, the most crucial factors are a change in policies, distrust between parties and non-enforcement of laws. Irrespective of position and designation in the project, clients, consultants, and constructors have identified these factors in independent surveys. If JV projects in Pakistan have to be strengthened, policymakers should mitigate these obstacles and remedy the risk causing factors.

\section{SUGGESTIONS AND RECOMMENDATIONS}

Some suggestions by experts to alleviate risk in the JV projects follow:

- Organizational goals should be defined clearly with the scope of the project and in compliance with $3 \mathrm{C}$ principles.

- $10 \%$ of workers on site and at each specific task should have sufficient qualification and the multilingual background to overcome communication concerns.

- Sufficient inflation cost should be included at the time of bidding.

- Consultants should be bound to weigh the project activities as per legislation.

- There should be weekly meetings among clients, consultants, and constructors.

TABLE II. CONTRACTUAL RISK ATTRIBUTES OF CJV PROJECTS IN PAKISTAN

\begin{tabular}{|c|c|c|c|c|c|c|}
\hline 1 & Undefined organizational goals & 4.78 & 4 & 3.63 & 4.13 & 0.48 \\
\hline 2 & Violation of contract by project partner & 3.16 & 4.41 & 4.73 & 4.1 & 0.68 \\
\hline 3 & Lack of organizational commitment & 3.8 & 4.01 & 4.29 & 4.03 & 0.20 \\
\hline 5 & Contractual terms not clear (from partner side) & 3.98 & 3.95 & 3.89 & 3.94 & 0.04 \\
\hline 6 & Ownership problem in project partner & 3.33 & 3.78 & 4.54 & 3.88 & 0.50 \\
\hline 7 & Undefined degree of agreement & 4.13 & 3.94 & 3.36 & 3.81 & 0.33 \\
\hline 8 & Less availability of information to partners & 3.98 & 3.88 & 3.03 & 3.63 & 0.43 \\
\hline 9 & Quality assurance & 2.89 & 3.19 & 4.42 & 3.5 & 0.66 \\
\hline 10 & Payment distribution & 3.19 & 2.89 & 4.06 & 3.38 & 0.50 \\
\hline 11 & Profit/loss distribution among partners & 2.94 & 3.18 & 3.81 & 3.31 & 0.37 \\
\hline 12 & Variation in payments & 2.77 & 3.47 & 3.69 & 3.31 & 0.39 \\
\hline 13 & Risk allocation & 3.16 & 2.93 & 3.48 & 3.19 & 0.23 \\
\hline 14 & Extension in time & 4.12 & 2.1 & 3.35 & 3.19 & 0.83 \\
\hline
\end{tabular}


TABLE III. CULTURAL RISK ATTRIBUTES OF CJV PROJECTS IN PAKISTAN

\begin{tabular}{|c|c|c|c|c|c|c|}
\hline 1 & Language differences between parties & 4.57 & 4.09 & 4.33 & 4.33 & 0.20 \\
\hline 2 & Lack of communication between parties & 4.13 & 4.18 & 4.56 & 4.29 & 0.19 \\
\hline 3 & Cultural differences between partners & 3.98 & 4.35 & 4.06 & 4.13 & 0.16 \\
\hline 4 & Social differences between partners & 2.76 & 3.33 & 3.9 & 3.33 & 0.47 \\
\hline 5 & Unfamiliarity with local conditions & 3.02 & 2.98 & 3.3 & 3.1 & 0.14 \\
\hline 6 & Clashes of parties while doing same work with different patterns & 2.24 & 2.1 & 2.65 & 2.33 & 0.23 \\
\hline
\end{tabular}

TABLE IV. FINANCIAL RISK ATTRIBUTES OF CJV PROJECTS IN PAKISTAN

\begin{tabular}{|c|c|c|c|c|c|c|}
\hline 1 & Labor and material price escalation & 4.11 & 4.02 & 4.56 & 4.23 & 0.24 \\
\hline 2 & Budget over run & 3.9 & 3.31 & 3.8 & 3.67 & 0.26 \\
\hline 3 & Loss due to variation of currency exchange rate & 4.1 & 3.13 & 3.78 & 3.67 & 0.40 \\
\hline 4 & Loss due to variation in interest rate & 3.74 & 3.07 & 3.69 & 3.5 & 0.30 \\
\hline 5 & Financial management issues with firm itself & 3.08 & 2.93 & 3.98 & 3.33 & 0.46 \\
\hline 6 & Change in market conditions & 3.13 & 3.36 & 3.5 & 3.33 & 0.15 \\
\hline 7 & Bankruptcy of project partner & 2.91 & 3.11 & 3.55 & 3.19 & 0.27 \\
\hline 8 & Poor consideration for inflation & 2.85 & 3.36 & 3.21 & 3.14 & 0.21 \\
\hline 9 & Low credibility of shareholders and lenders & 1.97 & 2.89 & 4.14 & 3 & 0.89 \\
\hline
\end{tabular}

TABLE V. MANAGERIAL RISK ATTRIBUTES OF CJV PROJECTS IN PAKISTAN

\begin{tabular}{|c|c|c|c|c|c|c|}
\hline 1 & Distrust between partner employees & 4.92 & 4.87 & 4.91 & 4.9 & 0.02 \\
\hline 2 & Incompetence of project management team & 4.88 & 4.37 & 4.91 & 4.72 & 0.25 \\
\hline 3 & Disagreement between both parties about staff allocation & 4.09 & 4.04 & 3.87 & 4 & 0.09 \\
\hline 4 & Improper project planning and budgeting & 4.11 & 3.31 & 4.07 & 3.83 & 0.37 \\
\hline 5 & Improper project feasibility study & 4.28 & 3.17 & 3.62 & 3.69 & 0.46 \\
\hline 6 & Inadequate choice of partner & 3.24 & 4.09 & 3.68 & 3.67 & 0.35 \\
\hline 7 & Poor relations with government departments & 3.28 & 3.34 & 3.37 & 3.33 & 0.04 \\
\hline 8 & Relationship with government & 4.01 & 2.42 & 3.56 & 3.33 & 0.67 \\
\hline 9 & Relationship with power groups & 2.88 & 3.12 & 3.99 & 3.33 & 0.48 \\
\hline 10 & Inadequate project organization structure & 4.02 & 2.68 & 3.29 & 3.33 & 0.55 \\
\hline 11 & Involvement of more decision makers & 3.11 & 2.86 & 3.54 & 3.17 & 0.28 \\
\hline 12 & poor relations and disputes with partners & 3.33 & 2.27 & 3.4 & 3 & 0.52 \\
\hline
\end{tabular}

TABLE VI. LEGAL RISK ATTRIBUTES OF CJV PROJECTS IN PAKISTAN

\begin{tabular}{|l|c|c|c|c|}
\hline 1 & lack of enforcement of legal laws & 4.52 & 4.47 & 4.9 \\
\hline 2 & no joint ventures laws & 4.12 & 3.63 & 0.19 \\
\hline 3 & difference of laws between partners & 3.13 & 3.88 & 4.24 \\
\hline
\end{tabular}

TABLE VII. POLICY AND POLITICAL RISK ATTRIBUTES OF CJV PROJECTS IN PAKISTAN

\begin{tabular}{|c|c|c|c|c|c|c|}
\hline 1 & Issues due to change in policies and political changes & 4.98 & 4.96 & 4.94 & 4.96 & 0.02 \\
\hline 2 & $\begin{array}{c}\text { Lack of project performance due to the involvement of political } \\
\text { stable partner }\end{array}$ & 4.79 & 4.56 & 4.18 & 4.51 & 0.25 \\
\hline 3 & Corruption and bribery & 3.82 & 4.08 & 4.19 & 4.03 & 0.16 \\
\hline 4 & Bureaucracy issues & 3.42 & 2.88 & 3.69 & 3.33 & 0.34 \\
\hline
\end{tabular}

\section{REFERENCES}

[1] A. Prasitsom, V. Likhitruangsilp, "Effects of organization structures on international construction joint venture risks", International Journal of Construction Engineering and Management, Vol. 4, No. 4, pp. 128-148, 2015

[2] X. Zhao, B. G. Hwang, G. S. Yu, "Identifying the critical risk in underground rail international construction joint ventures: Case study of Singapore", International Journal of Project Management, Vol. 31, No. 4, pp. 554-556, 2013

[3] Y. T. Roma, S. O. Ogunlana, "Chapter 3 Culture and Workplace Behavior: A Case Study of Joint venture Construction Projects in Thailand", in: Joint Ventures in Construction, , pp. 30-40, Thomas Telford Publishing, 2009

[4] V. Bagdonavicius, J. Kruopis, M. S. Nikulin, Non-parametric Tests for Complete Data, John Wiley \& Sons, 2011

[5] A. Prasitsom, A Life Cycle Risk Management and Prediction System for Construction Joint Ventures, $\mathrm{PhD}$ Thesis, Chulalongkorn University, Bangkok, Thailand, 2014
[6] A. Gale, J. Luo, "Factors affecting construction joint ventures in China", International Journal of Project Management, Vol. 22, No. 1, pp. 33-42, 2004

[7] K. Kobayashi, Joint ventures in construction, Thomas Telford Publishing, 2009

[8] C. Black, A. Akintoye, E. Fitzgerald, "An analysis of success factors and benefits of partnering in construction", International Journal of Project Management, Vol. 18, No. 6, pp. 423-434, 2000

[9] F. Y. K. Cheung, "Relationship management in the Australian construction industry-a grounded study", Symposium on CIB W92: Sustainability and value through construction procurement, Salford, UK, pp. 92-101, November 29-December 2, 2006

[10] J. Egan, Rethinking construction, construction task force report for the department of the environment, transport and the regions, HMSO, 1998

[11] A. Ashworth, S. Perera, Contractual procedures in the construction industry, Routledge, 2018

[12] K. M. Hmieleski, R. A. Baron, "Entrepreneurs' optimism and new venture performance: A social cognitive perspective", Academy of Management Journal, Vol. 52, No. 3, pp. 473-488, 2009 
[13] B. G. Hwang, X. Zhao, E. W. Y. Chin, "International construction joint ventures between Singapore and developing countries: Risk assessment and allocation preferences", Engineering, Construction and Architectural Management, Vol. 24, No. 2, pp. 209-228, 2017

[14] B. G. Hwang, X. Zhao, L. P. Toh, "Risk management in small construction projects in Singapore: Status, barriers, and impact", International Journal of Project Management, Vol. 32, No. 1, pp. 116124,2014

[15] X. Deng, S. P. Low, Q. Li, X. Zhao, "Developing competitive advantages in political risk management for international construction enterprises", Journal of Construction Engineering and Management, Vol. 140, No. 9, 2014

[16] H. Park, K. W. Lee, H. D. Jeong, S. H. Han, "Effect of institutional risks on the performance of international construction projects", Construction Research Congress 2014: Construction in a Global Network, Atlanta, USA, pp. 2126-2135, May 19-21, 2014

[17] S. P. Low, J. Liu, S. He, "External risk management practices of Chinese construction firms in Singapore", KSCE Journal of Civil Engineering, Vol. 13, No. 2, pp. 85-95, 2009

[18] C. Berk, "A risk management proposal to the international contractor's industry from the financial perspective", Journal of Applied Finance and Banking, Vol. 2, No. 5, p. 199, 2012

[19] J. D. Frame, Managing risk in organizations: A guide for managers, John Wiley \& Sons, 2003

[20] A. Ardeshir, M. Amiri, Y. Ghasemi, M. Errington, "Risk assessment of construction projects for water conveyance tunnels using fuzzy fault tree analysis", International Journal of Civil Engineering, Vol. 12, No. 4, pp. 396-412, 2014

[21] F. Nasirzadeh, H. Mazandaranizadeh, M. Rouhparvar, "Quantitative risk allocation in construction projects using cooperative-bargaining game theory", International Journal of Civil Engineering, Vol. 14, No. 3, pp. 161-170, 2016

[22] G. Zhang, P. X. Zou, "Fuzzy analytical hierarchy process risk assessment approach for joint venture construction projects in China", Journal of Construction Engineering and Management, Vol. 133, No. 10, pp. 771-779, 2007

[23] M. Abdelgawad, A. R. Fayek, "Risk management in the construction industry using combined fuzzy FMEA and fuzzy AHP”, Journal of Construction Engineering and Management, Vol. 136, No. 9, pp. 1028-1036, 2010

[24] F. Siddiqui, A. R. Khoso, A. A. Pathan, M .A. Akhund, S. H. Khahro, "Concept and Willingness to Adopt Zero Energy Buildings", Indian Journal of Science and Technology, Vol. 11, No. 5, 2018

[25] M. A. Akhund, A. R. Khoso, U. Memon, S. H. Khahro, "Time Overrun in Construction Projects of Developing Countries", Imperial Journal of Interdisciplinary Research, Vol. 3, No. 5, pp. 124-129, 2017 